\title{
Daniel O'Connell
}





\title{
Daniel O’Connell
}

\author{
Nationalism \\ Without Violence
}

\author{
an essay by \\ RAYMOND MOLEY
}

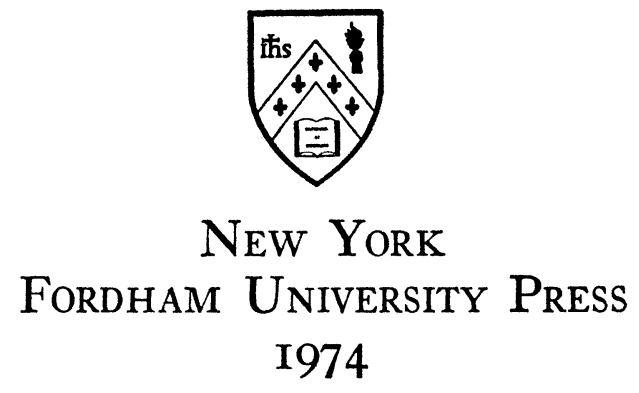


(C) Copyright 1974 by Fordham University Press All rights reserved.

ISBN $0-8232-0977-6$

LC $73-93142$

First edition. Limited to I,, 00 copies.

Printed in the United States of America 


\section{To my grandmother Mary Ann Kane Molé}


